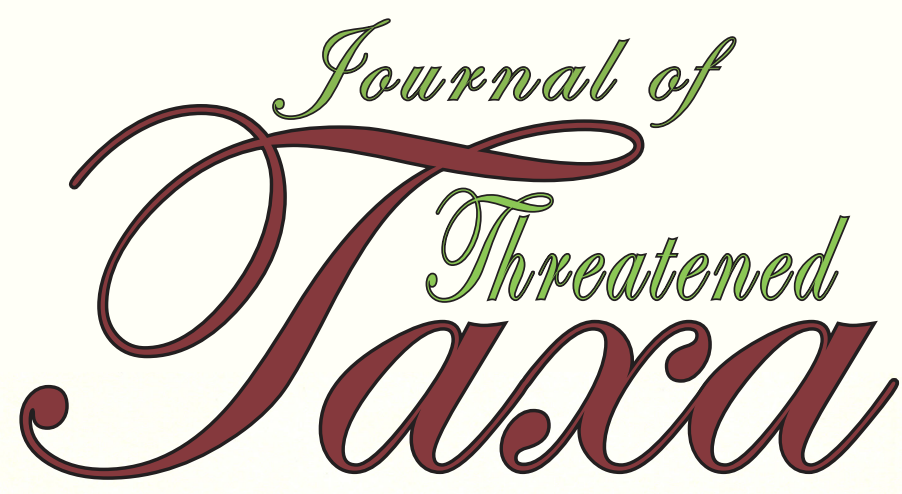

10.11609/jott.2021.13.14.20143-20310 enever.threatenedtaxa.org

26 December 2021 (Online \& Print) Val. 13 | Na. 14 | Pages: 20143-20310 155n 0974-7907 (Online) 155n 0974-7893 (Print)

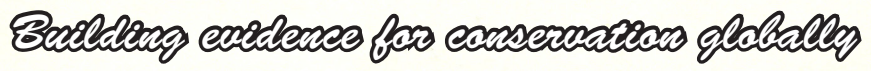

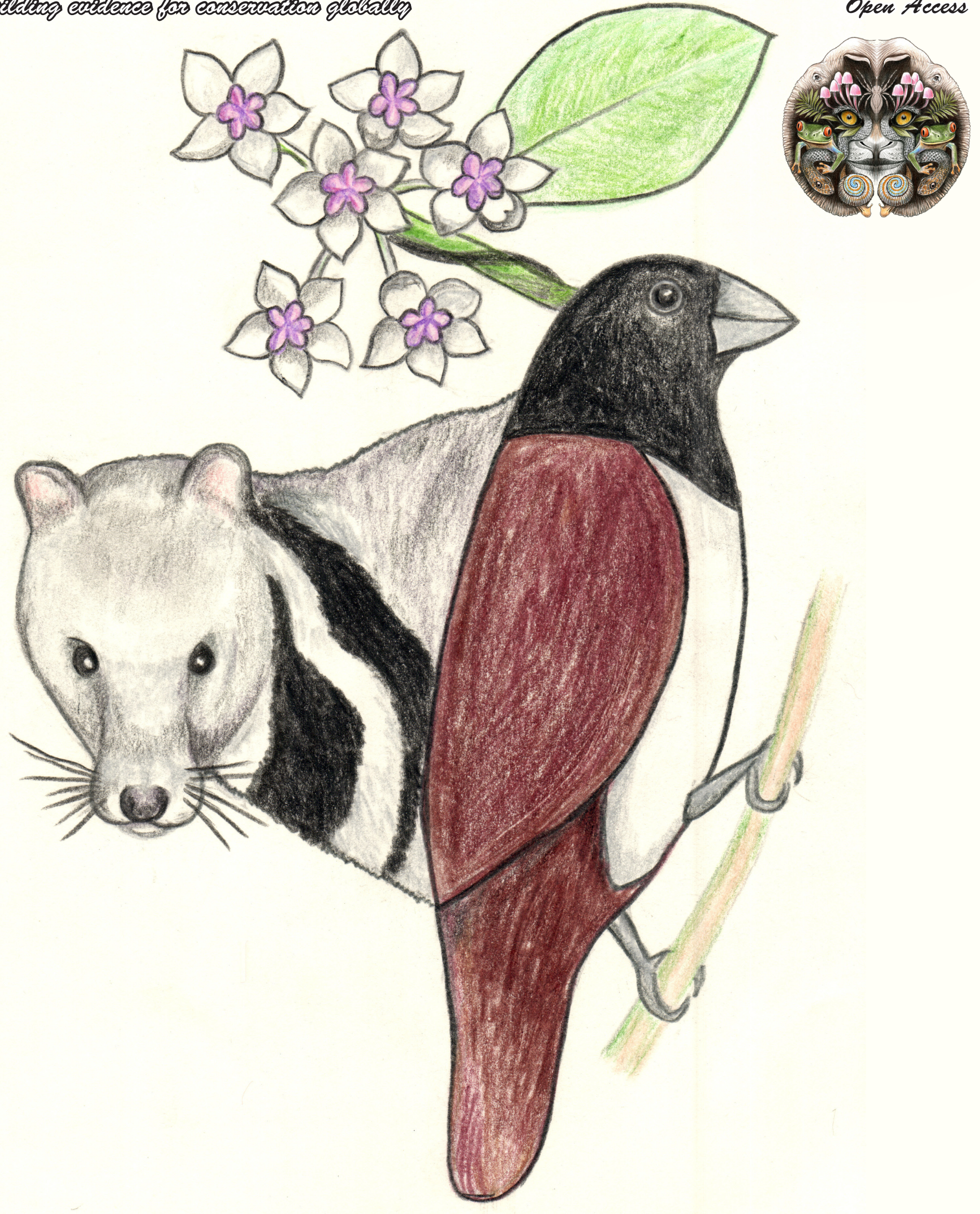

Open Access 


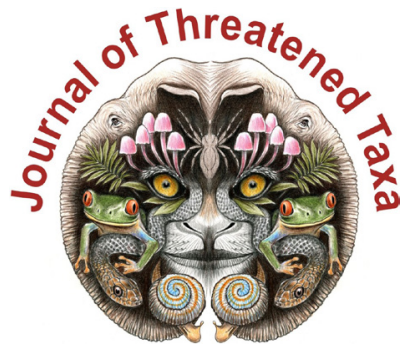

ISSN 0974-7907 (Online); ISSN $0974-7893$ (Print)

Publisher

Host

Wildlife Information Liaison Development Society

www.wild.zooreach.org

Zoo Outreach Organization www.zooreach.org

No. 12, Thiruvannamalai Nagar, Saravanampatti - Kalapatti Road, Saravanampatti, Coimbatore, Tamil Nadu 641035, India

Ph: +91 9385339863 | www.threatenedtaxa.org

Email: sanjay@threatenedtaxa.org

EDITORS

\section{Founder \& Chief Editor}

Dr. Sanjay Molur

Wildlife Information Liaison Development (WILD) Society \& Zoo Outreach Organization (ZOO),

12 Thiruvannamalai Nagar, Saravanampatti, Coimbatore, Tamil Nadu 641035, India

\section{Deputy Chief Editor}

Dr. Neelesh Dahanukar

Noida, Uttar Pradesh, India

\section{Managing Editor}

Mr. B. Ravichandran, WILD/ZOO, Coimbatore, India

\section{Associate Editors}

Dr. Mandar Paingankar, Government Science College Gadchiroli, Maharashtra 442605, India

Dr. Ulrike Streicher, Wildlife Veterinarian, Eugene, Oregon, USA

Ms. Priyanka lyer, ZOO/WILD, Coimbatore, Tamil Nadu 641035, India

Dr. BA. Daniel, $200 / \mathrm{WILD}$, Coimbatore, Tamil Nadu 641035, India

\section{Editorial Board}

Dr. Russel Mittermeie

Executive Vice Chair, Conservation International, Arlington, Virginia 22202, USA

\section{Prof. Mewa Singh Ph.D., FASc, FNA, FNASc, FNAPsy}

Ramanna Fellow and Life-Long Distinguished Professor, Biopsychology Laboratory, and Institute of Excellence, University of Mysore, Mysuru, Karnataka 570006, India; Honorary Professor, Jawaharlal Nehru Centre for Advanced Scientific Research, Bangalore; and Adjunct Professor, National Institute of Advanced Studies, Bangalore

\section{Stephen D. Nash}

Scientific Illustrator, Conservation International, Dept. of Anatomical Sciences, Health Sciences Center, T-8, Room 045, Stony Brook University, Stony Brook, NY 11794-8081, USA

\section{Dr. Fred Pluthero}

Toronto, Canada

\section{Dr. Priya Davidar}

Sigur Nature Trust, Chadapatti, Mavinhalla PO, Nilgiris, Tamil Nadu 643223, India

\section{Dr. Martin Fisher}

Senior Associate Professor, Battcock Centre for Experimental Astrophysics, Cavendish

Laboratory, JJ Thomson Avenue, Cambridge CB3 OHE, UK

\section{Dr. John Fellowes}

Honorary Assistant Professor, The Kadoorie Institute, 8/F, T.T. Tsui Building, The University of Hong Kong, Pokfulam Road, Hong Kong

\section{Prof. Dr. Mirco Solé}

Universidade Estadual de Santa Cruz, Departamento de Ciências Biológicas, Vice-coordenado do Programa de Pós-Graduação em Zoologia, Rodovia Ilhéus/Itabuna, Km 16 (45662-000)

Salobrinho, Ilhéus - Bahia - Brasil

\section{Dr. Rajeev Raghavan}

Professor of Taxonomy, Kerala University of Fisheries \& Ocean Studies, Kochi, Kerala, India

\section{English Editors}

Mrs. Mira Bhojwani, Pune, India

Dr. Fred Pluthero, Toronto, Canad

Mr. P. Ilangovan, Chennai, India

Web Development

Mrs. Latha G. Ravikumar, ZOO/WILD, Coimbatore, India

\section{Typesetting}

Mr. Arul Jagadish, ZOO, Coimbatore, India

Mrs. Radhika, ZOO, Coimbatore, India

Mrs. Geetha, ZOO, Coimbatore India
Fundraising/Communications

Mrs. Payal B. Molur, Coimbatore, India

Subject Editors 2018-2020

Fungi

Dr. B. Shivaraju, Bengaluru, Karnataka, India

Dr. R.K. Verma, Tropical Forest Research Institute, Jabalpur, India

Dr. Vatsavaya S. Raju, Kakatiay University, Warangal, Andhra Pradesh, India

Dr. M. Krishnappa, Jnana Sahyadri, Kuvempu University, Shimoga, Karnataka, India

Dr. K.R. Sridhar, Mangalore University, Mangalagangotri, Mangalore, Karnataka, India

Dr. Gunjan Biswas, Vidyasagar University, Midnapore, West Bengal, India

\section{Plants}

Dr. G.P. Sinha, Botanical Survey of India, Allahabad, India

Dr. N.P. Balakrishnan, Ret. Joint Director, BSI, Coimbatore, India

Dr. Shonil Bhagwat, Open University and University of Oxford, UK

Prof. D.J. Bhat, Retd. Professor, Goa University, Goa, India

Dr. Ferdinando Boero, Università del Salento, Lecce, Italy

Dr. Dale R. Calder, Royal Ontaro Museum, Toronto, Ontario, Canada

Dr. Cleofas Cervancia, Univ. of Philippines Los Baños College Laguna, Philippines

Dr. F.B. Vincent Florens, University of Mauritius, Mauritius

Dr. Merlin Franco, Curtin University, Malaysia

Dr. V. Irudayaraj, St. Xavier's College, Palayamkottai, Tamil Nadu, India

Dr. B.S. Kholia, Botanical Survey of India, Gangtok, Sikkim, India

Dr. Pankaj Kumar, Kadoorie Farm and Botanic Garden Corporation, Hong Kong S.A.R., China

Dr. V. Sampath Kumar, Botanical Survey of India, Howrah, West Bengal, India

Dr. A.J. Solomon Raju, Andhra University, Visakhapatnam, India

Dr. Vijayasankar Raman, University of Mississippi, USA

Dr. B. Ravi Prasad Rao, Sri Krishnadevaraya University, Anantpur, India

Dr. K. Ravikumar, FRLHT, Bengaluru, Karnataka, India

Dr. Aparna Watve, Pune, Maharashtra, India

Dr. Qiang Liu, Xishuangbanna Tropical Botanical Garden, Yunnan, China

Dr. Noor Azhar Mohamed Shazili, Universiti Malaysia Terengganu, Kuala Terengganu, Malaysia

Dr. M.K. Vasudeva Rao, Shiv Ranjani Housing Society, Pune, Maharashtra, India

Prof. A.J. Solomon Raju, Andhra University, Visakhapatnam, India

Dr. Mandar Datar, Agharkar Research Institute, Pune, Maharashtra, India

Dr. M.K. Janarthanam, Goa University, Goa, India

Dr. K. Karthigeyan, Botanical Survey of India, India

Dr. Errol Vela, University of Montpellier, Montpellier, France

Dr. P. Lakshminarasimhan, Botanical Survey of India, Howrah, India

Dr. Larry R. Noblick, Montgomery Botanical Center, Miami, USA

Dr. K. Haridasan, Pallavur, Palakkad District, Kerala, India

Dr. Analinda Manila-Fajard, University of the Philippines Los Banos, Laguna, Philippines

Dr. P.A. Sinu, Central University of Kerala, Kasaragod, Kerala, India

Dr. Afroz Alam, Banasthali Vidyapith (accredited A grade by NAAC), Rajasthan, India

Dr. K.P. Rajesh, Zamorin's Guruvayurappan College, GA College PO, Kozhikode, Kerala, India

Dr. David E. Boufford, Harvard University Herbaria, Cambridge, MA 02138-2020, USA

Dr. Ritesh Kumar Choudhary, Agharkar Research Institute, Pune, Maharashtra, India

Dr. Navendu Page, Wildlife Institute of India, Chandrabani, Dehradun, Uttarakhand, India

\section{Invertebrates}

Dr. R.K. Avasthi, Rohtak University, Haryana, India

Dr. D.B. Bastawade, Maharashtra, India

Dr. Partha Pratim Bhattacharjee, Tripura University, Suryamaninagar, India

Dr. Kailash Chandra, Zoological Survey of India, Jabalpur, Madhya Pradesh, India

Dr. Ansie Dippenaar-Schoeman, University of Pretoria, Queenswood, South Africa

Dr. Rory Dow, National Museum of natural History Naturalis, The Netherlands

Dr. Brian Fisher, California Academy of Sciences, USA

Dr. Richard Gallon, llandudno, North Wales, LL30 1UP

Dr. Hemant V. Ghate, Modern College, Pune, India

Dr. M. Monwar Hossain, Jahangirnagar University, Dhaka, Bangladesh

Mr. Jatishwor Singh Irungbam, Biology Centre CAS, Branišovská, Czech Republic.

Dr. Ian J. Kitching, Natural History Museum, Cromwell Road, UK

Dr. George Mathew, Kerala Forest Research Institute, Peechi, India

For Focus, Scope, Aims, and Policies, visit https://threatenedtaxa.org/index.php/JoTT/aims_scope
For Article Submission Guidelines, visit https://threatenedtaxa.org/index.php/JoTT/about/submissions
For Policies against Scientific Misconduct, visit https://threatenedtaxa.org/index.php/JoTT/policies_various 


\title{
Latrine site and its use pattern by Large Indian Civet Viverra zibetha Linnaeus, 1758: record from camera trap
}

\author{
Bhuwan Singh Bist ${ }^{1}\left(\mathbb{D}\right.$, Prashant Ghimire ${ }^{2}(\mathbb{D})$, Basant Sharma ${ }^{3}(\mathbb{D})$, Chiranjeevi Khanal ${ }^{4} \mathbb{C}$ \\ \& Anoj Subedi ${ }^{5}$ (D)
}

\footnotetext{
${ }^{1}$ The School of Forestry and Natural Resource Management, Institute of Forestry(IOF), Tribhuvan University(TU), Kathmandu, Nepal.

${ }^{3,4}$ Faculty of Science, Health and Technology, Nepal Open University, Lalitpur, Nepal.

1,2,3,5 Institute of Forestry, Pokhara Campus, Tribhuvan University, Pokhara 33700, Nepal. ${ }^{1}$ bhuwanbistaiof@gmail.com (corresponding author), ${ }^{2}$ prashantghimire66@gmail.com, ${ }^{3}$ b.s.sharma237@gmail.com, ${ }^{4}$ chirankhanal1@gmail.com, ${ }^{5}$ anojsubedi99@gmail.com
}

\begin{abstract}
Latrine sites are the places used for urination and defecation which mostly act as a signaling agent for multiple purposes like territorial marking, confrontation with extruders or potential predators, delivering different inter and intra-communication messages. To understand latrine site visit pattern, a single camera trap was deployed for 91 trap nights at the latrine site of Large Indian Civet during the months of December 2016 and February \& March 2017. Latrine site was found under the tree with abundant crown cover and bushes. At least two individuals were found to be using a single latrine site in an irregular manner between $1800 \mathrm{~h}$ and $0600 \mathrm{~h}$ with higher activity between $1800 \mathrm{~h}$ and $2300 \mathrm{~h}$. Our results indicated an irregular latrine site visit pattern, hence similar studies with a robust research design in larger areas are required to understand specific latrine use patterns
\end{abstract}

Keywords: Activity pattern, behavior, camera trap, clock chart, seasonal, scent marking, territorial marking, territory, urination.

The repeated use of specific latrine sites has been described for several mammals, including omnivores, ungulates, and primates (Dröscher \& Kappeler 2014). Such sites vary in location (arboreal, terrestrial, or subterranean), in volume of faeces, spatial distribution, and behaviours associated with defecation and seem to vary in the functions they serve (Irwin et al. 2004).
Understanding the use of latrine sites is one of the most effective and fundamental tools that provides future directions and insights into the ecological and behavioural relationships among conspecifics. Time stamped camera trap data have been very useful for understanding the presence, ecology and behaviour of the species (Ridout \& Linkie 2009; Rowcliffe et al. 2014).

The Large Indian Civet Viverra zibetha is a widespread species and has been recorded up to $2,420 \mathrm{~m}$ in Nepal (Appel et al. 2013), and up to 3,080 m in India (Khatiwara \& Srivastava 2014). Its presence was documented in the riverine and Sal Shorea robusta forests, near human settlements (Ghimirey \& Acharya 2014), grasslands and in thick bushes (Jnawali et al. 2011) as well as in the primary, secondary, degraded forest, scrubland and plantations areas (Duckworth 1997; Azlan 2003; Jennings \& Veron 2011; Choudhury 2013; Chutipong et al. 2014). Due to its wide distribution across a variety of habitats, it is listed as Least Concern (LC) in IUCN Red List (Timmins et al. 2016). It is a ground dwelling (Lekagul \& McNeely 1977; Duckworth 1997) solitary, nocturnal animal; with occasional records at daytime (Than et al.

Editor: Honnavalli N. Kumara, Salim Ali Centre for Ornithology and Natural History, Coimbatore, India. Date of publication: 26 December 2021 (online \& print) Citation: Bist, B.S., P. Ghimire, B. Sharma, C. Khanal \& A. Subedi (2021). Latrine site and its use pattern by Large Indian Civet Viverra zibetha Linnaeus, 1758: record from camera trap. Journal of Threatened Taxa 13(14): 20284-20287. https://doi.org/10.11609/jott.6685.13.14.20284-20287

Copyright: @ Bist et al. 2021. Creative Commons Attribution 4.0 International License. JoTT allows unrestricted use, reproduction, and distribution of this article in any medium by providing adequate credit to the author(s) and the source of publication.

Funding: This research received no specific grant from any funding agency, or commercial or not-for-profit sectors.

Competing interests: The authors declare no competing interests.

Acknowledgements: Our team thanks Kritagaya Gyawali, Milan Budha, Milan Aryal, Gaurav Raaz Baral, Anup Raaz Adhikari, and Navin Pandey for assisting in the field; Yajna Prasad Timilsina, Angelika Appeal, and Russel Gray for their help in different stages; and all anonymous reviewers for comments on the drafts. 
2008; Gray et al. 2014). In this note, we documented its latrine site and its use pattern in the premises of the Institute of Forestry, Pokhara, using camera trap records.

\section{Study area}

The Institute of Forestry (IOF), Pokhara campus is situated in Pokhara, Kaski district, Gandaki province of Nepal. We identified the latrine site of the Large Indian Civet during mammalian profile survey within Banpale forest, a legal asset of IOF, which mainly includes the natural Schima-Castanopsis forest; having species of Dalbergia, Albezia, Michelia, and Alnus. The Seti river is a perennial that flows within a close vicinity of the forest. The recorded latrine site was very close to the Marshyangdi hostel. Agricultural crops, vegetables, and banana gardens were found around the study site.

\section{MATERIAL AND METHODS}

A single piece of Bushnell camera trap was deployed without any lure for 91 days from 1-30 December 2016 and 01 February to 30 March 2017. The camera trap, having active motion inbuilt function with non-motion sensor, was deployed at the base of a $D$. sissoo tree at a height of $25-30 \mathrm{~cm}$ above the ground in such a way that the entire latrine site was visible. It was set to both photo and video mode option so as to record two photos per second followed by a video of 10 seconds from 1800-0600 h for each trap night.

\section{Data analysis}

Both photo and video from the camera trap were imported, collated, and cleaned for further analysis. Only those photos and videos with the evidence of the record of a Large Indian Civet in the latrine site were considered for the interpretation. The obtained data were analyzed in $\mathrm{R}$ software using the package ggplot2, dplyr, lubridate ( $R$ core team 2019) to create the clock chart.

\section{RESULTS}

The geographic location of the latrine site was at an elevation of $808 \mathrm{~m}$. Monitoring of the latrine site for three months yielded a total of 215 videos and 1,017 camera trap images during the effort of 91 camera trap nights.

The latrine site was under the bush coverage of a $D$. sissoo tree, with $80 \%$ canopy intertwined with bushes and climbers, making the site enclosed with openings at two ends. The defecating site was excavated 5-cm deep at the center of the pit (a cavity or hole in the ground usually made by digging). The individuals deposited the feces along with spraying of urine in the latrine site, and rubbing their anus in soil right after defecation. Two

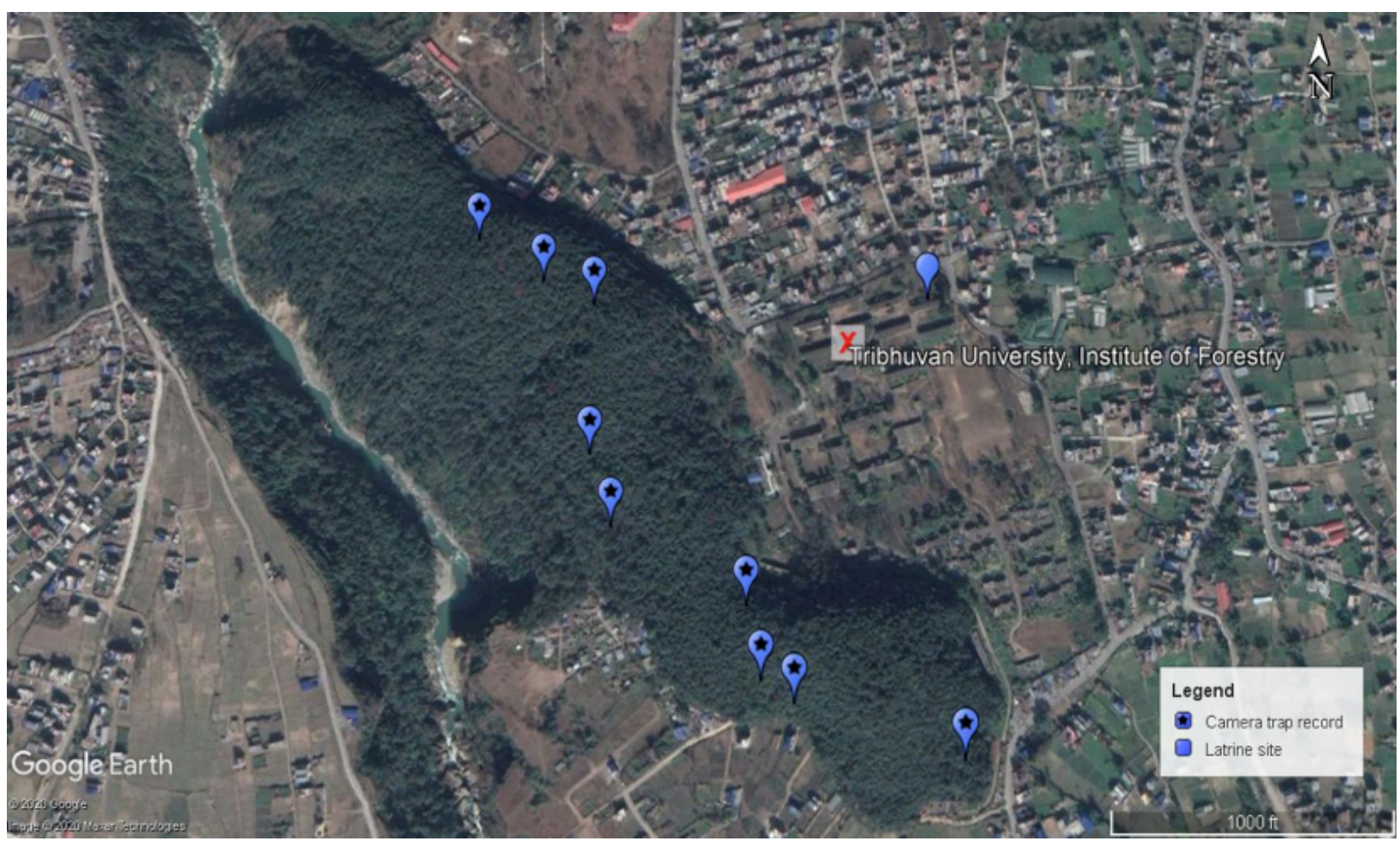

Image 1. Map of the study area (camera trap recorded locations of Large Indian Civet in the Banpale forest and latrine site at backside of Marsyangdi hostel at Institute of Forestry, Pokhara Campus, Nepal). 
Large Indian Civets were seen together in the recorded video of March 2017 in the latrine site, however, their sexes could not be distinguished.

Large Indian Civets visited the latrine site from 1800 $0500 \mathrm{~h}$ (Figure 1). It was active for most of the night time with the highest record during the hour between (2100$2200 \mathrm{~h})$ followed by (1800-1900 h), with the lowest at the start of the day (0500-0600 h). It visited the site for eight days in December, seven days in February and six days in March. After the first eight days of frequent visits, the animal was not observed for the next 22 days in December.

Of the total video duration $(1,423$ seconds), the presence of the Large Indian Civet was recorded for 1,046 seconds, the major activity during this was sniffing (782 seconds, 78\%) and defecating \& urinating (224 seconds, 22\%). It initially sniffed the site, afterwards urinated and defecated.

\section{Discussion}

The recorded latrine site was outside the forest area and in close proximity to the settlement area. A tree surrounded by tall bushes with a small outlet in both sides was used by the Large Indian Civet as latrine site.

Irregular visits to the monitored latrine site suggest that the animals have maintained other latrine sites too. A species maintaining more than one latrine site can be attributed to territory marking such as in otters (Torgerson 2014) and could be an interesting aspect of study. It could be a special vigilance behavior of the small carnivores to avoid any risk or conflict around the habitat.

The Malay Civets Viverra tangalunga were predominantly active from $1800 \mathrm{~h}$ to $0700 \mathrm{~h}$ (Colon 2006), and reported frequent walking and sniffing as a physiological olfactory sense use of carnivores to check the potential predator and conspecifics before the use of the latrine site for defecation and urination. This could be attributed as a special form of scent marking serving as a commonly invoked chemical communication function (Irwin et al. 2004; Wronski et al. 2013; Dröscher \& Kappeler 2014; King et al. 2017) for avoidance of parasite transmission (Gilbert 1997), avoidance of detection by predators (Boonstra et al. 1996), and territoriality (Gorman \& Trowbridge 1989). The nocturnal and crepuscular activity would help in increasing the encounters with prey (Colon 2006), a similar behavior was observed in our current study.
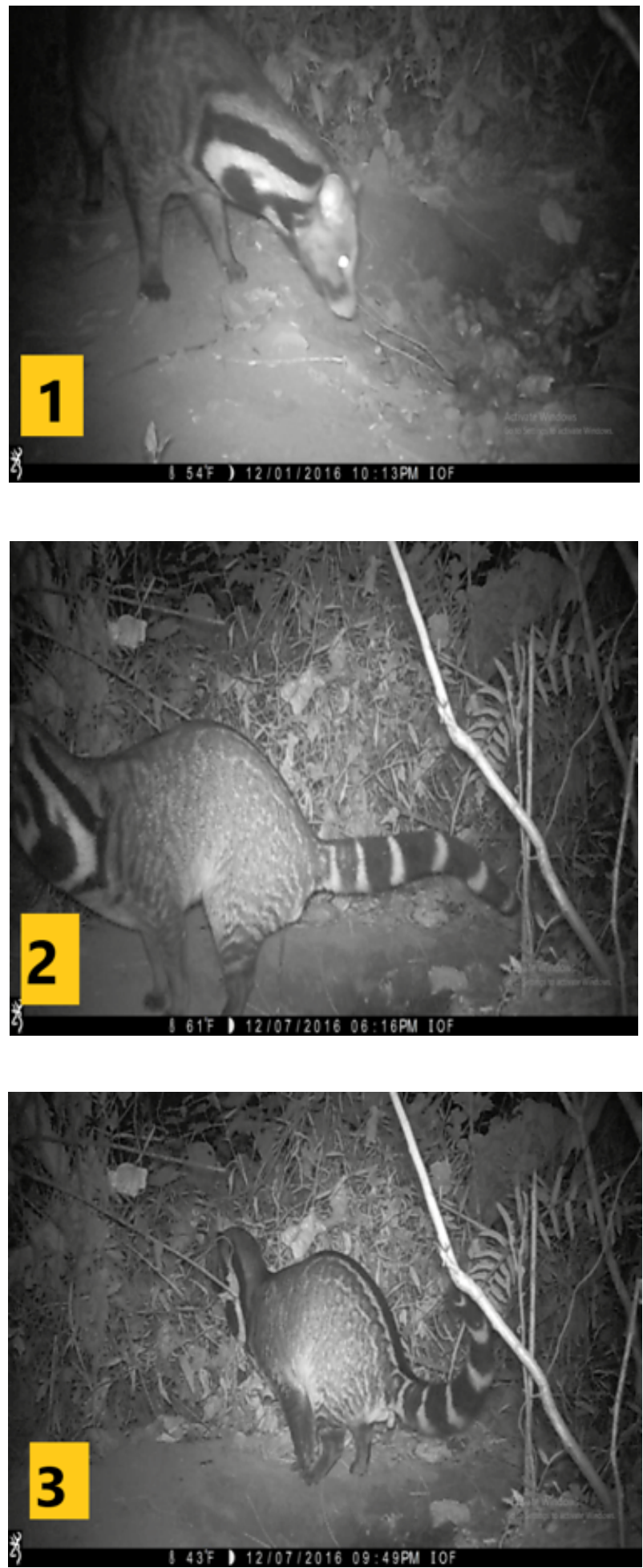

Image 2. Camera trapped photographs taken from the video recorded during the latrine site monitoring of Large Indian Civet: 1-the latrine trench of the species marked by yellow circle | 2-species urinating on its latrine site | 3-species defecating on its latrine site. 

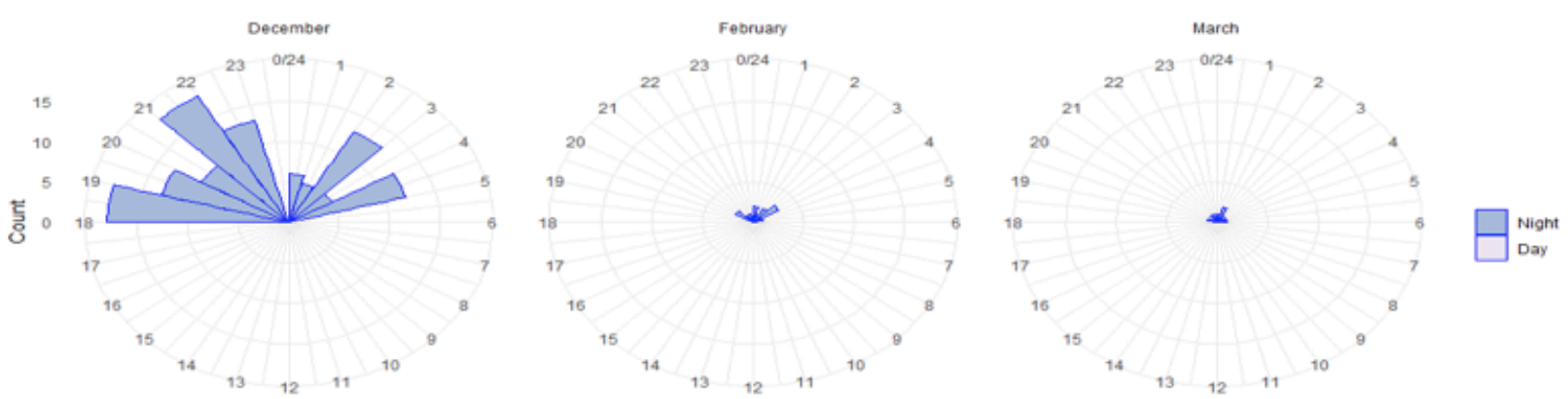

Figure 1. Frequency of camera-trap photographs and videographs of Large Indian Civet during survey period (1800-0500 $\mathrm{h}$ has been treated as night while the rest is day).

\section{REFERENCES}

Appel, A., G. Werhahn, R. Acharya, Y. Ghimirey \& B. Adhikary (2013) Small carnivores in the Annapsurna Conservation Area, Nepal. Vertebrate Zoology 63: 111-121.

Azlan, J. (2003). The diversity and conservation of mustelids, viverrids, and herpestids in a disturbed forest in Peninsular Malaysia. Small Carnivore Conservation 29: 8-9.

Boonstra, R., C.J. Krebs \& A. Kenney (1996). Why lemmings have indoor plumbing in summer. Canadian. Journal of Zoology 74 1947-1949.

Choudhury, A. (2013). The Mammals of North East India. Gibbon Books and the Rhino Foundation for Nature in NE India, Guwahati, Assam, India.

Chutipong, W., N. Tantipisanuh, D. Ngoprasert, A.J. Lynam, R. Steinmetz, K.E. Jenks, J.L. Grassman, M. Tewes, S. Kitamura, M.C. Baker, W. McShea, N. Bhumpakphan, R. Sukmasuang, G.A. Gale, F.K. Harich, A.C. Treydte, P. Cutter, P.B. Cutter, S. Suwanrat, K. Siripattaranukul, Hala-Bala Wildlife Research Station, Wildlife Research Division \& J.W. Duckworth (2014). Current distribution and conservation status of small carnivores in Thailand: a baseline review. Small Carnivore Conservation 51: 96-136.

Colon, C. (2006). Ranging behaviour and activity of the Malay civet (Viverra tangalunga) in a logged and an unlogged forest in Danum Valley, East Malaysia. Journal of Zoology 257: 473- 485. https:// doi.org/10.1017/S0952836902001073

Gray, T.N.E., C. Pin, C. Phan, R. Crouthers, J.F. Kamler \& S. Prum (2014). Camera-trap records of small carnivores from eastern Cambodia, 1999-2013. Small Carnivore Conservation 50: 20-24

Dröscher, I. \& P. Kappeler (2014). Maintenance of familiarity and social bonding via communal latrine use in a solitary primate (Lepilemur leucopus). Behavioral Ecology and Sociobiology 68: 2043-2058. https://doi.org/10.1007/s00265-014-1810-z

Duckworth, J.W. (1997). Small carnivores in Laos: a status review with notes on ecology, behaviour and conservation. Small Carnivore Conservation 16: 1-21.

Ghimirey, Y. \& R. Acharya (2014). Notes on the distribution of Large Indian Civet in Nepal. Small Carnivore Conservation 50: 25-29.

Gorman, M.L. \& B.J. Trowbridge (1989). The role of odor in the social lives of carnivores, pp. 57-88. In: Gittleman, J.L. (ed.). Carnivore Behavior, Ecology, and Evolution. Cornell University Press, Ithaca, New York.

Gilbert, K.A. (1997). Red howling monkey use of specific defecation sites as a parasite avoidance strategy. Animal Behavior 54: 451455.

Irwin, M., K. Samonds, J.L. Raharison \& P. Wright (2004). Lemur latrines: Observations of latrine behavior in wild primates and possible ecological significance. Journal of Mammalogy 85: 420427. https://doi.org/10.1644/1545-1542(2004)085<0420:LLOOLB $>2.0 . \mathrm{CO} ; 2$

Jnawali, S.R., H.S. Baral, S. Lee, K.P. Acharya, G.P. Upadhyay, M. Pandey, R. Shrestha, D. Joshi, B.R. Laminchhane, J. Griffiths, A.P. Khatiwada, N. Subedi \& R. Amin (compilers) (2011). The Status of Nepal Mammals: The National Red List Series, Department of National Parks and Wildlife Conservation Kathmandu, Nepal.

Jennings, A.P. \& G. Veron (2011). Predicted distributions and ecological niches of 8 civet and mongoose species in Southeast Asia. Journal of Mammalogy 92: 316-327.

Khatiwara, S. \& T. Srivastava (2014). Red Panda Ailurus fulgens and other small carnivores in Kyongnosla Alpine Sanctuary, East Sikkim, India. Small Carnivore Conservation 50: 35-38.

King, T., R. Salom, L. Shipley, H. Quigley \& D. Thornton (2017). Ocelot latrines: communication centers for Neotropical mammals. Journal of Mammalogy 98: 106-113. https://doi.org/10.1093/ jmammal/gyw174

Lekagul, B. \& J.A. McNeely (1977). Mammals of Thailand. Association for the Conservation of Wildlife, Bangkok, Thailand, 758pp.

R Core Team (2019). R: A language and environment for statistical computing. R Foundation for Statistical Computing, Vienna, Austria.URL https://www.R-project.org/

Rowcliffe, J., M.R. Kays, B. Kranstauber, C. Carbone \& P.A. Jansen (2014). Quantifying levels of animal activity using camera trap data. Methods Ecology Evolution 5: 1170-1179.

Ridout, M.S. \& M. Linkie (2009). Estimating overlap of daily activity patterns from camera trap data. Journal of Agricultural, Biological, and Environmental Statistics 14: 322-337.

Torgerson, T. (2014). Latrine site selection and seasonal habitat use of a coastal river otter population. A Thesis Presented to The Faculty of Humboldt State University In Partial Fulfillment of the Requirements for the Degree Master of Science in Natural Resources: Wildlife, xi+91pp. https://doi.org/10.13140/ RG.2.2.35183.43685

Than, Z., H. Saw, Po. Tha, M. Myint, A.J. Lynam, T.L. Kyaw \& J.W. Duckworth (2008). Status and distribution of small carnivores in Myanmar. Small Carnivore Conservation 38: 2-28.

Timmins, R..J., J.W. Duckworth, W. Chutipong, Y. Ghimirey, D.H.A. Willcox, H. Rahman, B. Long \& A. Choudhury (2016). Viverra zibetha. The IUCN Red List of Threatened Species 2016: e.T41709A45220429. Accessed 19 May 2020. https://doi. org/10.2305/IUCN.UK.20161.RLTS.T41709A45220429.en

Wronski, T., A. Apio, M. Plath \& M. Ziege (2013). Sex difference in the communicatory significance of localized defecation sites in Arabian Gazelles (Gazella arabica). Journal of Ethology 31: 129140. 
Dr. John Noyes, Natural History Museum, London, UK

Dr. Albert G. Orr, Griffith University, Nathan, Australia

Dr. Sameer Padhye, Katholieke Universiteit Leuven, Belgium

Dr. Nancy van der Poorten, Toronto, Canada

Dr. Kareen Schnabel, NIWA, Wellington, New Zealand

Dr. R.M. Sharma, (Retd.) Scientist, Zoological Survey of India, Pune, India

Dr. Manju Siliwal, WILD, Coimbatore, Tamil Nadu, India

Dr. G.P. Sinha, Botanical Survey of India, Allahabad, India

Dr. K.A. Subramanian, Zoological Survey of India, New Alipore, Kolkata, India

Dr. P.M. Sureshan, Zoological Survey of India, Kozhikode, Kerala, India

Dr. R. Varatharajan, Manipur University, Imphal, Manipur, India

Dr. Eduard Vives, Museu de Ciències Naturals de Barcelona, Terrassa, Spain

Dr. James Young, Hong Kong Lepidopterists' Society, Hong Kong

Dr. R. Sundararaj, Institute of Wood Science \& Technology, Bengaluru, India

Dr. M. Nithyanandan, Environmental Department, La Ala Al Kuwait Real Estate. Co. K.S.C.,

Kuwait

Dr. Himender Bharti, Punjabi University, Punjab, India

Mr. Purnendu Roy, London, UK

Dr. Saito Motoki, The Butterfly Society of Japan, Tokyo, Japan

Dr. Sanjay Sondhi, TITLI TRUST, Kalpavriksh, Dehradun, India

Dr. Nguyen Thi Phuong Lien, Vietnam Academy of Science and Technology, Hanoi, Vietnam

Dr. Nitin Kulkarni, Tropical Research Institute, Jabalpur, India

Dr. Robin Wen Jiang Ngiam, National Parks Board, Singapore

Dr. Lional Monod, Natural History Museum of Geneva, Genève, Switzerland.

Dr. Asheesh Shivam, Nehru Gram Bharti University, Allahabad, India

Dr. Rosana Moreira da Rocha, Universidade Federal do Paraná, Curitiba, Brasi

Dr. Kurt R. Arnold, North Dakota State University, Saxony, Germany

Dr. James M. Carpenter, American Museum of Natural History, New York, USA

Dr. David M. Claborn, Missouri State University, Springfield, USA

Dr. Kareen Schnabel, Marine Biologist, Wellington, New Zealand

Dr. Amazonas Chagas Júnior, Universidade Federal de Mato Grosso, Cuiabá, Brasil

Mr. Monsoon Jyoti Gogoi, Assam University, Silchar, Assam, India

Dr. Heo Chong Chin, Universiti Teknologi MARA (UiTM), Selangor, Malaysia

Dr. R.J. Shiel, University of Adelaide, SA 5005, Australia

Dr. Siddharth Kulkarni, The George Washington University, Washington, USA

Dr. Priyadarsanan Dharma Rajan, ATREE, Bengaluru, India

Dr. Phil Alderslade, CSIRO Marine And Atmospheric Research, Hobart, Australia

Dr. John E.N. Veron, Coral Reef Research, Townsville, Australia

Dr. Daniel Whitmore, State Museum of Natural History Stuttgart, Rosenstein, Germany.

Dr. Yu-Feng Hsu, National Taiwan Normal University, Taipei City, Taiwan

Dr. Keith V. Wolfe, Antioch, California, USA

Dr. Siddharth Kulkarni, The Hormiga Lab, The George Washington University, Washington,

D.C., USA

Dr. Tomas Ditrich, Faculty of Education, University of South Bohemia in Ceske

Budejovice, Czech Republic

Dr. Mihaly Foldvari, Natural History Museum, University of Oslo, Norway

Dr. V.P. Uniyal, Wildlife Institute of India, Dehradun, Uttarakhand 248001, India

Dr. John T.D. Caleb, Zoological Survey of India, Kolkata, West Bengal, India

Dr. Priyadarsanan Dharma Rajan, Ashoka Trust for Research in Ecology and the Environment

(ATREE), Royal Enclave, Bangalore, Karnataka, India

\section{Fishes}

Dr. Neelesh Dahanukar, IISER, Pune, Maharashtra, India

Dr. Topiltzin Contreras MacBeath, Universidad Autónoma del estado de Morelos, México

Dr. Heok Hee Ng, National University of Singapore, Science Drive, Singapore

Dr. Rajeev Raghavan, St. Albert's College, Kochi, Kerala, India

Dr. Robert D. Sluka, Chiltern Gateway Project, A Rocha UK, Southall, Middlesex, UK

Dr. E. Vivekanandan, Central Marine Fisheries Research Institute, Chennai, India

Dr. Davor Zanella, University of Zagreb, Zagreb, Croatia

Dr. A. Biju Kumar, University of Kerala, Thiruvananthapuram, Kerala, India

Dr. Akhilesh K.V., ICAR-Central Marine Fisheries Research Institute, Mumbai Research

Centre, Mumbai, Maharashtra, India

Dr. J.A. Johnson, Wildlife Institute of India, Dehradun, Uttarakhand, India

Amphibians

Dr. Sushil K. Dutta, Indian Institute of Science, Bengaluru, Karnataka, India

Dr. Annemarie Ohler, Muséum national d'Histoire naturelle, Paris, France

\section{Reptiles}

Dr. Gernot Vogel, Heidelberg, Germany

Dr. Raju Vyas, Vadodara, Gujarat, India

Dr. Pritpal S. Soorae, Environment Agency, Abu Dubai, UAE.

Prof. Dr. Wayne J. Fuller, Near East University, Mersin, Turkey

Prof. Chandrashekher U. Rivonker, Goa University, Taleigao Plateau, Goa. India

Dr. S.R. Ganesh, Chennai Snake Park, Chennai, Tamil Nadu, India

Dr. Himansu Sekhar Das, Terrestrial \& Marine Biodiversity, Abu Dhabi, UAE
Birds

Dr. Hem Sagar Baral, Charles Sturt University, NSW Australia

Dr. Chris Bowden, Royal Society for the Protection of Birds, Sandy, UK

Dr. Priya Davidar, Pondicherry University, Kalapet, Puducherry, India

Dr. J.W. Duckworth, IUCN SSC, Bath, UK

Dr. Rajah Jayapal, SACON, Coimbatore, Tamil Nadu, India

Dr. Rajiv S. Kalsi, M.L.N. College, Yamuna Nagar, Haryana, India

Dr. V. Santharam, Rishi Valley Education Centre, Chittoor Dt., Andhra Pradesh, India

Dr. S. Balachandran, Bombay Natural History Society, Mumbai, India

Mr. J. Praveen, Bengaluru, India

Dr. C. Srinivasulu, Osmania University, Hyderabad, India

Dr. K.S. Gopi Sundar, International Crane Foundation, Baraboo, USA

Dr. Gombobaatar Sundev, Professor of Ornithology, Ulaanbaatar, Mongolia

Prof. Reuven Yosef, International Birding \& Research Centre, Eilat, Israel

Dr. Taej Mundkur, Wetlands International, Wageningen, The Netherlands

Dr. Carol Inskipp, Bishop Auckland Co., Durham, UK

Dr. Tim Inskipp, Bishop Auckland Co, Durham, UK

Dr. V. Gokula, National College, Tiruchirappalli, Tamil Nadu, India

Dr. Arkady Lelej, Russian Academy of Sciences, Vladivostok, Russia

Dr. Simon Dowell, Science Director, Chester Zoo, UK

Dr. Mário Gabriel Santiago dos Santos, Universidade de Trás-os-Montes e Alto Douro,

Quinta de Prados, Vila Real, Portugal

Dr. Grant Connette, Smithsonian Institution, Royal, VA, USA

Dr. M. Zafar-ul Islam, Prince Saud Al Faisal Wildlife Research Center, Taif, Saudi Arabia

Mammals

Dr. Giovanni Amori, CNR - Institute of Ecosystem Studies, Rome, Italy

Dr. Anwaruddin Chowdhury, Guwahati, India

Dr. David Mallon, Zoological Society of London, UK

Dr. Shomita Mukherjee, SACON, Coimbatore, Tamil Nadu, India

Dr. Angie Appel, Wild Cat Network, Germany

Dr. P.O. Nameer, Kerala Agricultural University, Thrissur, Kerala, India

Dr. Ian Redmond, UNEP Convention on Migratory Species, Lansdown, UK

Dr. Heidi S. Riddle, Riddle's Elephant and Wildlife Sanctuary, Arkansas, USA

Dr. Karin Schwartz, George Mason University, Fairfax, Virginia.

Dr. Lala A.K. Singh, Bhubaneswar, Orissa, India

Dr. Mewa Singh, Mysore University, Mysore, India

Dr. Paul Racey, University of Exeter, Devon, UK

Dr. Honnavalli N. Kumara, SACON, Anaikatty P.O., Coimbatore, Tamil Nadu, India

Dr. Nishith Dharaiya, HNG University, Patan, Gujarat, India

Dr. Spartaco Gippoliti, Socio Onorario Società Italiana per la Storia della Fauna "Giuseppe

Altobello", Rome, Italy

Dr. Justus Joshua, Green Future Foundation, Tiruchirapalli, Tamil Nadu, India

Dr. H. Raghuram, The American College, Madurai, Tamil Nadu, India

Dr. Paul Bates, Harison Institute, Kent, UK

Dr. Jim Sanderson, Small Wild Cat Conservation Foundation, Hartford, USA

Dr. Dan Challender, University of Kent, Canterbury, UK

Dr. David Mallon, Manchester Metropolitan University, Derbyshire, UK

Dr. Brian L. Cypher, California State University-Stanislaus, Bakersfield, CA

Dr. S.S. Talmale, Zoological Survey of India, Pune, Maharashtra, India

Prof. Karan Bahadur Shah, Budhanilakantha Municipality, Kathmandu, Nepal

Dr. Susan Cheyne, Borneo Nature Foundation International, Palangkaraja, Indonesia

Dr. Hemanta Kafley, Wildlife Sciences, Tarleton State University, Texas, USA

\section{Other Disciplines}

Dr. Aniruddha Belsare, Columbia MO 65203, USA (Veterinary)

Dr. Mandar S. Paingankar, University of Pune, Pune, Maharashtra, India (Molecular)

Dr. Jack Tordoff, Critical Ecosystem Partnership Fund, Arlington, USA (Communities)

Dr. Ulrike Streicher, University of Oregon, Eugene, USA (Veterinary)

Dr. Hari Balasubramanian, EcoAdvisors, Nova Scotia, Canada (Communities)

Dr. Rayanna Hellem Santos Bezerra, Universidade Federal de Sergipe, São Cristóvão, Brazil

Dr. Jamie R. Wood, Landcare Research, Canterbury, New Zealand

Dr. Wendy Collinson-Jonker, Endangered Wildlife Trust, Gauteng, South Africa

Dr. Rajeshkumar G. Jani, Anand Agricultural University, Anand, Gujarat, India

Dr. O.N. Tiwari, Senior Scientist, ICAR-Indian Agricultural Research Institute (IARI), New

Delhi, India

Dr. L.D. Singla, Guru Angad Dev Veterinary and Animal Sciences University, Ludhiana, India

Dr. Rupika S. Rajakaruna, University of Peradeniya, Peradeniya, Sri Lanka

Dr. Bahar Baviskar, Wild-CER, Nagpur, Maharashtra 440013, India

Reviewers 2018-2020

Due to pausity of space, the list of reviewers for $2018-2020$ is available online.

The opinions expressed by the authors do not reflect the views of the Journal of Threatened Taxa, Wildlife Information Liaison Development Society, Zoo Outreach Organization, or any of the partners. The journal, the publisher, the host, and the partners are not responsible for the accuracy of the political boundaries shown in the maps by the authors.

Journal of Threatened Taxa is indexed/abstracted in Bibliography of Systematic Mycology, Biological Abstracts, BIOSIS Previews, CAB Abstracts, EBSCO, Google Scholar, Index Copernicus, Index Fungorum, JournalSeek, National Academy of Agricultural Sciences, NewJour, OCLC WorldCat, SCOPUS, Stanford University Libraries, Virtual Library of Biology, Zoological Records.

NAAS rating (India) 5.64
Print copies of the Journal are available at cost. Write to:

The Managing Editor, JoTT,

c/o Wildlife Information Liaison Development Society,

No. 12, Thiruvannamalai Nagar, Saravanampatti - Kalapatti Road,

Saravanampatti, Coimbatore, Tamil Nadu 641035, India

ravi@threatenedtaxa.org 


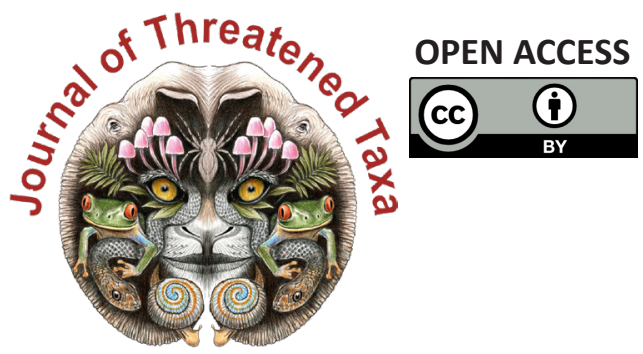

www.threatenedtaxa.org

The Journal of Threatened Taxa (JoTT) is dedicated to building evidence for conservation globally by publishing peer-reviewed articles online every month at a reasonably rapid rate at www.threatenedtaxa.org. All articles published in JoTT are registered under Creative Commons Attribution 4.0 International License unless otherwise mentioned. JoTT allows allows unrestricted use, reproduction, and distribution of articles in any medium by providing adequate credit to the author(s) and the source of publication.

\section{ISSN $0974-7907$ (Online) | ISSN $0974-7893$ (Print)}

\section{December 2021 | Vol. 13 | No. 14 | Pages: 20143-20310 \\ Date of Publication: 26 December 2021 (Online \& Print) DOI: 10.11609/jott.2021.13.14.20143-20310}

\section{Communications}

Updated distribution of seven Trichosanthes L. (Cucurbitales: Cucurbitaceae) taxa in India, along with taxonomic notes

Kanakasabapathi Pradheep, Soyimchiten, Ganjalagatta Dasaiah Harish, Muhammed Abdul Nizar, Kailash Chandra Bhatt, Anjula Pandey \& Sudhir Pal Ahlawat, Pp. 20143-20152

Dragonflies and Damselflies (Insecta: Odonata) of Aryanad Grama Panchayat, Kerala, India

- Reji Chandran \& A. Vivek Chandran, Pp. 20153-20166

Checklist of Odonata (Insecta) of Doon Valley, Uttarakhand, India

- Kritish De, Sarika Bhatt, Amar Paul Singh, Manisha Uniyal \& Virendra Prasad Uniyal, Pp. 20167-20173

Diversity of moths from the urban set-up of Valmiki Nagar, Chennai, India - Vikas Madhav Nagarajan, Rohith Srinivasan \& Mahathi Narayanaswamy, Pp. 20174-20189

Ichthyofaunal diversity with relation to environmental variables in the snowfed Tamor River of eastern Nepal

- Jawan Tumbahangfe, Jash Hang Limbu, Archana Prasad, Bhrarat Raj Subba \& Dil Kumar Limbu, Pp. 20190-20200

Observations on the foraging behavior of Tricoloured Munia Lonchura malacca (Linnaeus, 1766) and its interaction with pearl millet fields in Villupuram District, Tamil Nadu, India

- M. Pandian, Pp. 20201-20208

Roosting patterns of House Sparrow Passer domesticus Linn., 1758 (Aves: Passeridae) in Bhavnagar, Gujarat, India

- Foram P. Patel \& Pravinsang P. Dodia, Pp. 20209-20217

Review

Comprehensive checklist of algal class Chlorophyceae (sensu Fritsch, 1935) for Uttar Pradesh, India, with updated taxonomic status

- Sushma Verma, Kiran Toppo \& Sanjeeva Nayaka, Pp. 20218-20248

\section{View Point}

Wildlife managers ignore previous knowledge at great risk: the case of Rivaldo, the iconic wild Asian Elephant Elephas maximus L. of the Sigur Region, Nilgiri Biosphere Reserve, India

- Jean-Philippe Puyravaud \& Priya Davidar, Pp. 20249-20252

\section{Short Communications}

Diversity and distribution of macro lichens from Kalpetta Municipality of Wayanad District, Kerala, India

- Greeshma Balu, A.R. Rasmi, Stephen Sequeira \& Biju Haridas, Pp. 20253-20257

Extended distribution of two endemic epiphytes from the Western Ghats to the Deccan Plateau

- Sonali Vishnu Deore, Mangala Dala Sonawane \& Sharad Suresh Kambale, Pp. 20258-20260

Nomenclatural notes and report of Boehmeria penduliflora Wedd. ex D.G. Long from the Terai region of Uttar Pradesh, India

- Amit Gupta, Imtiyaz Ahmad Hurrah, Aparna Shukla \& Vijay V. Wagh, Pp. 2026120265
New distribution record of a true coral species, Psammocora contigua (Esper, 1794) from Gulf of Kachchh Marine National Park \& Sanctuary, India - R. Chandran, R. Senthil Kumaran, D.T. Vasavada, N.N. Joshi \& Osman G. Husen, Pp. 20266-20271

A new species of flat-headed mayfly Afronurus meenmutti (Ephemeroptera: Heptageniidae: Ecdyonurinae) from Kerala, India

- Marimuthu Muthukatturaja \& Chellaiah Balasubramanian, Pp. 20272-20277

Photographic record of Dholes predating on a young Banteng in southwestern Java, Indonesia

- Dede Aulia Rahman, Mochamad Syamsudin, Asep Yayus Firdaus, Herry Trisna Afriandi \& Anggodo, Pp. 20278-20283

Latrine site and its use pattern by Large Indian Civet Viverra zibetha Linnaeus, 1758: record from camera trap

- Bhuwan Singh Bist, Prashant Ghimire, Basant Sharma, Chiranjeevi Khanal \& Anoj Subedi, Pp. 20284-20287

Notes

Two additions to the flora of Kerala, India

- P. Murugan, Basil Paul \& M. Sulaiman, Pp. 20288-20291

Pentatropis R.Br. ex Wight \& Arn. (Apocynaceae), a new generic record for Kerala, India

- V. Ambika, Jose Sojan \& V. Suresh, Pp. 20292-20294

New record of Kashmir Birch Mouse Sicista concolor leathemi (Thomas, 1893) (Rodentia: Sminthidae) in the Indian Himalaya

- S.S. Talmale, Avtar Kaur Sidhu \& Uttam Saikia, Pp. 20295-20298

Breeding record of Black-headed Ibis Threskiornis melanocephalus (Aves: Threskiornithidae) at Mavoor wetland, Kozhikode District, Kerala, India - C.T. Shifa, Pp. 20299-20301

\section{Response}

Crop and property damage caused by Purple-faced Langurs Trachypithecus vetulus (Mammalia: Primates: Cercopithecidae) - Vincent Nijman, Pp. 20302-20306

Reply

If habitat heterogeneity is effective for conservation of butterflies in urban landscapes of Delhi, India? Unethical publication based on data manipulation: Response of original authors

- Monalisa Paul \& Aisha Sultana, Pp. 20307-20308

\section{Book Review}

Freshwater fishes of the Arabian Peninsula - Rajeev Raghavan, Pp. 20309-20310

Publisher \& Host

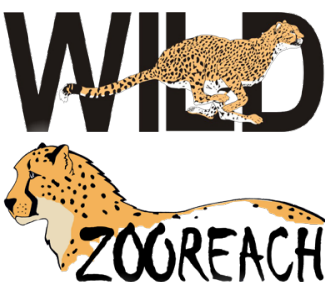

Threatened Taxa 